
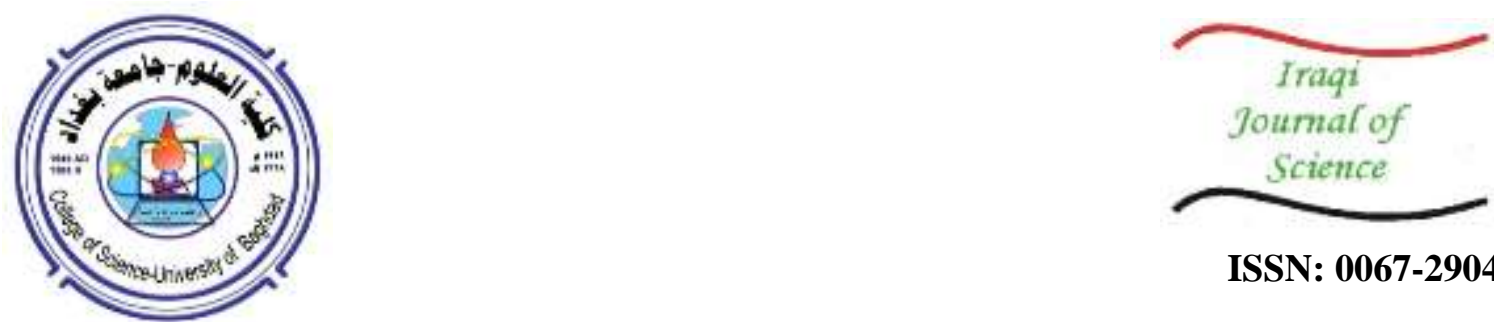

ISSN: 0067-2904

\title{
Analysis of Climate Parameters as Indicators of Climate Changes in Central and Eastern Iraq: Khanaqin Climate Conditions as A Case Study
}

\author{
Ismail Ahmed Ibrahim*, Moutaz Al-Dabbas \\ Department of Geology, College of Science, Baghdad University, Baghdad, Iraq
}

Received: 27/10/2020

Accepted: 12/2/2021

\begin{abstract}
The climate parameters of rainfall, and average of maximum and minimum temperature were investigated for the period of 2000-2019 in three stations in central and eastern Iraq (Baghdad, Diyala, and Kut provinces). Evidence of climate change was noticed from the results, reflected by decreased mean values of annual rainfall with increased mean of maximum and minimum temperature. In addition, the water balance and the climatic conditions were determined for Khanaqin station for the years 1981-2019. The analysis of Khanaqin climate parameters demonstrated total annual mean values of rainfall of $260.86 \mathrm{~mm}$ and evaporation of $3119.59 \mathrm{~mm}$. The mean monthly relative humidity was $46.65 \%$, sunshine was $8.39 \mathrm{~h} /$ day, temperature was $23.36 \mathrm{C}^{\circ}$ and wind speed was $1.86 \mathrm{~m} / \mathrm{sec}$. Water surplus was recorded in Khanaqin area, with values of $(24.00 \mathrm{~mm})(34.18 \mathrm{~mm})(40.31 \mathrm{~mm})(28.83 \mathrm{~mm})$ and $(19.92 \mathrm{~mm})$ in November, December, January, February and March respectively. The climate classification of Khanaqin area indicated semi dry and dry climates. Moreover, the region has water deficit that reached up to $43.56 \%$ of the total rainfall values.
\end{abstract}

Keywords: climate change, water balance, climate conditions, Central and southern Iraq.

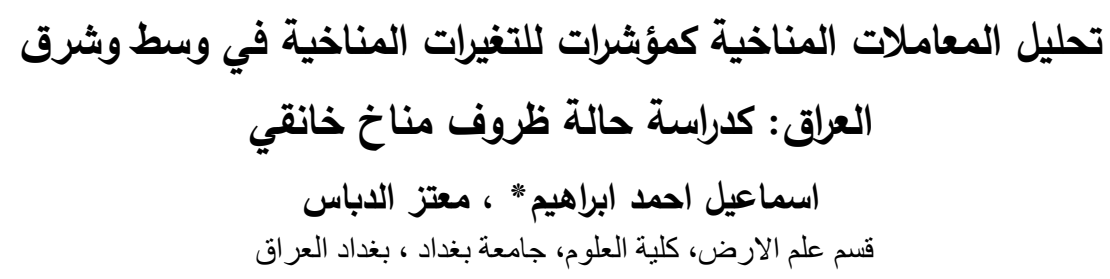




\section{Introduction}

Iraq is one of the countries of the Middle East and North African region (MENA) and characterized by arid and semi-arid climate [1]. The country is currently facing a serious water shortage problem. This problem is expected to be more severe in the future due to the global climate change [1]. The global mean annual air temperature increased by approximately $0.5^{\circ} \mathrm{C}$ between 1850 and 1990 [2].

Carbon dioxide $\left(\mathrm{CO}_{2}\right)$, a major cause of climate change, is naturally released from the volcanic eruptions and respiration. It is dissolved in the oceans and consumed during plant photosynthesis. Currently, there are 359 parts per million by volume (ppmv) of $\mathrm{CO}_{2}$ in the atmosphere, while the concentration is becoming higher because of human contributions [3].

The amount of water, especially freshwater, is limited in Iraq as it is characterizing by semiarid climate [4]. Several aspects of socio-economic, physical, and climate change facts play an important role in contributing to the recent pressure on freshwater resources. These will significantly impact water resource management in the future. Climate change is probably going to prompt a more prominent reliance on water and an incremented unreliability in surface water accessibility [5].

Many researches have published on the hydrochemical and hydraulic properties of the Iraqi groundwater [6]. Less research has involved the future harmful impacts of climatic change on the utilization of groundwater basins in Iraq. The issues of the increasing population and climate change effects on water resources aggravate the water disputes in the basin. Water resources are mainly controlled by the climate conditions. Accordingly, global warming will have evolving impacts on water resources and pose important challenges to sustainable development. Therefore, it is vital to focus on potential implications of climate change on the Iraqi water resources through studying and analyzing the available climate parameters.

The purpose of this work is to demonstrate examples of climatic change impacts in Iraq by investigating the climate data parameters of temperature and rainfall for a selected area. The study covered globally-published data on the climate of Baghdad, Diyala, and Wasit governorates for the period 2000-2019. The investigate from the local climatic data of NASA agency for the period 1981-2019 by determine the climate type and climate water balance.

\section{Materials and Methods}

\section{The Study Area}

In this research, we have selected a region in three governorates, namely Baghdad, Diyala, and Wasit, located in central and eastern Iraq (Figure 1). The available data of climatic parameters were collected and analyzed for the years 2000-2019 based on the US National Aeronautics and Space Administration (NASA) database [4]. Also, local climate data for the period 1981-2019 were collected from NASA agency of Khanaqin area, which is located in Diyala Governorate to the east of Diyala river at the Iraqi-Iranian border between longitudes $45^{\circ} 09^{\prime}-45^{\circ} 36^{\prime} \mathrm{E}$ and latitudes $34^{\circ} 12^{\prime}-34^{\circ} 39^{\prime} \mathrm{N}$ (Figure 1). Its total area is equal to $1100 \mathrm{Km}^{2}$. Al-Wand River is a permanent stream that also passes through the area and drains its water to Diyala River. The Khanaqin area is part of the unstable shelf within the low folded zone of Hemrin belt, which is represented by the foot hill zone. The age of the exposed rocks in the basin ranges between the Middle Miocene, represented by Fatha formation, and the Holocene Flood Plain deposits. The quaternary deposits cover the entire area, which includes Fatha Formation (Miocene age), the Injana Formation (Miocene age), the Mukdadiya Formation (Pliocene age), and the Bai Hassan Formation (upper Pliocene age). The Mukdadiya and Bai Hassan formations are the main groundwater aquifers in the area and the recharge from rainfall [7].

\section{Climatic parameter analysis in the flood plain of Mesopotamia}

Three representative stations were selected for the climatic parameters analysis. Khanaqin 
(Diyala) and Kut (Wasit) stations were chosen to represent the eastern parts of the Mesopotamia plain and part of the foothill zone of Iraq, whereas Baghdad station was chosen to represent the flood plain of Mesopotamia in the center of Iraq. The available data for about 19 years records of the studied climatic elements (2000-2019), such as the mean annual temperature and the mean annual rainfall, were collected from NASA agency [4].

\section{The analysis of the climatic parameters of Khanaqin Station}

Khanaqin station was selected to represent the eastern part of Iraq near the folded zone. The historical climate data of the Khanaqin station for the years 1981 to 2019 were analyzed to investigate the climate water balance with determination of the mean monthly climatic parameters of sunshine, wind speed, relative humidity, precipitation, evaporation, and temperature (Table 1) [4]. Values of potential evapotranspiration were determined following the methods of Thornthwiat 1948 [8] and Lerner et al. 1990 [9]. These methods were applied to compute water balance in the study area. Type of climate of Khanaqin area was determined according to the climate classifications of Koeppen 2006 [10], Brown and Cocheme 1973 [11], and Mather 1974 [12].

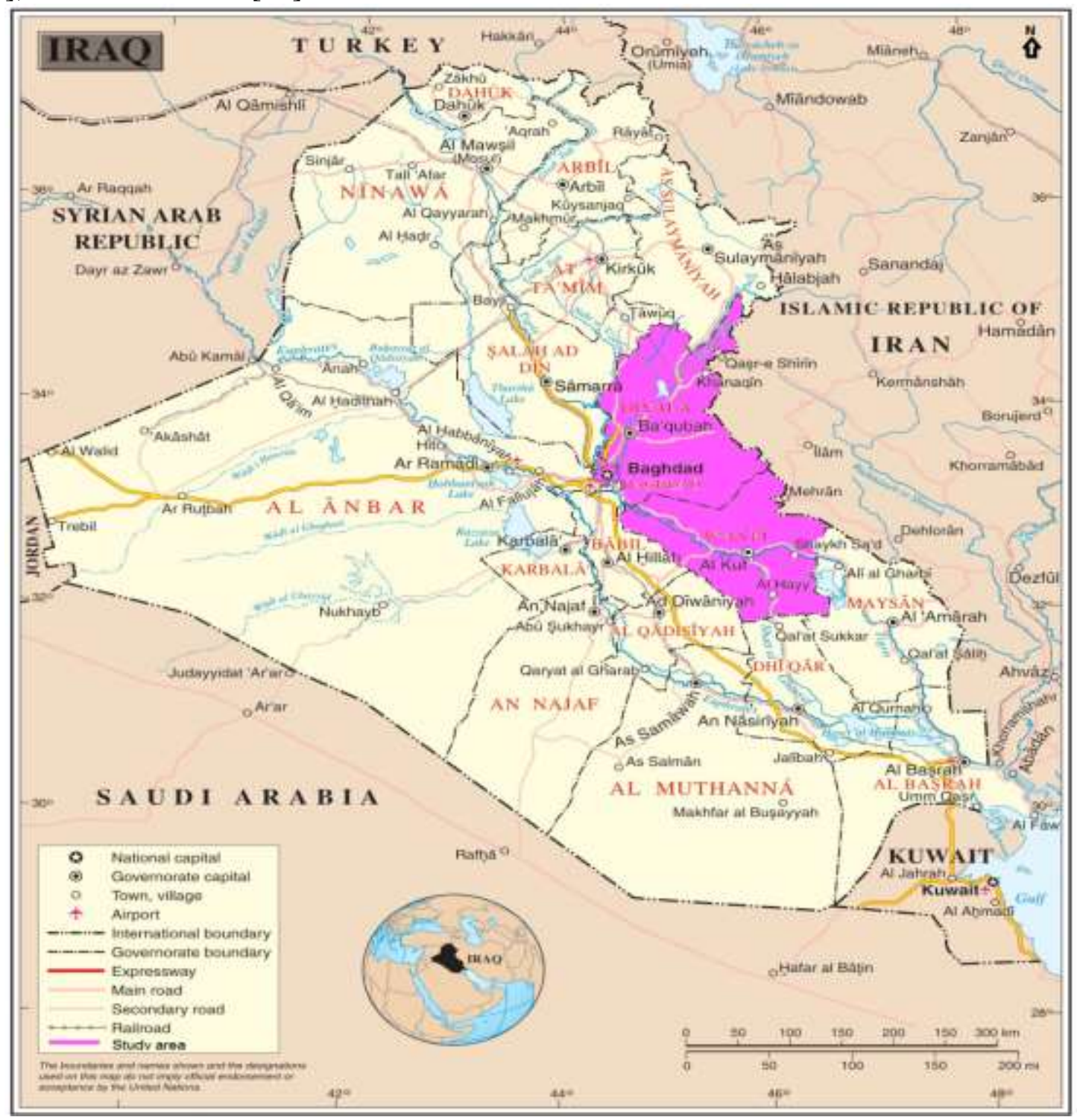

Figure 1- Iraq map showing the location of the study area (purple color) 
Table 1- Monthly averages of the climatic elements for the years 1981 to 2019 in Khanaqin station [4].

\begin{tabular}{|l|l|l|l|l|l|l|}
\hline Months & $\begin{array}{l}\text { Sunshine } \\
(\mathbf{h} / \mathbf{d a y})\end{array}$ & $\begin{array}{l}\text { Temperature } \\
\left(\mathbf{C}^{\mathbf{0}}\right)\end{array}$ & $\begin{array}{l}\text { Wind speed } \\
(\mathbf{m} / \mathbf{s e c})\end{array}$ & $\begin{array}{l}\text { Evaporation } \\
(\mathbf{m m})\end{array}$ & $\begin{array}{l}\text { Relative } \\
\text { Humidity } \\
(\boldsymbol{\%})\end{array}$ & $\begin{array}{l}\text { Rainfall } \\
(\mathbf{m m})\end{array}$ \\
\hline Oct. & 7.21 & 25.77 & 1.77 & 231.49 & 37.43 & 14.73 \\
\hline Nov. & 6.94 & 17.33 & 1.54 & 113.52 & 58.17 & 42.92 \\
\hline Dec. & 6.69 & 12.15 & 1.48 & 75.39 & 72.10 & 41.66 \\
\hline Jan. & 5.21 & 10.10 & 1.63 & 66.27 & 75.12 & 43.92 \\
\hline Feb. & 6.67 & 11.97 & 1.92 & 99.03 & 67.71 & 35.31 \\
\hline Mar. & 7.95 & 15.96 & 2.08 & 174.86 & 60.07 & 37.99 \\
\hline Apr. & 9.27 & 21.63 & 2.30 & 244.98 & 50.47 & 29.40 \\
\hline May. & 10.53 & 28.60 & 2.17 & 346.28 & 36.11 & 11.25 \\
\hline Jun. & 10.06 & 33.31 & 2.15 & 456.29 & 25.91 & 0.84 \\
\hline Jul. & 11.33 & 36.13 & 1.94 & 510.50 & 23.93 & 0.50 \\
\hline Aug. & 10.77 & 35.79 & 1.73 & 458.02 & 24.74 & 0.64 \\
\hline Sep. & 7.99 & 31.60 & 1.58 & 342.96 & 27.99 & 1.71 \\
\hline Average & 8.39 & 23.36 & 1.86 & & 46.65 & \\
\hline Total & & & & 3119.59 & & 260.86 \\
\hline
\end{tabular}

\section{Results and Discussion}

\section{Climatic parameter analysis}

The frequency curves of annual rainfall $(\mathrm{mm}) \backslash$, annual relative humidity \% (RH \%), and annual mean temperature (Average, Maximum, and Minimum) for historical data in Khanaqin (Diyala) were studied (Figure 2). The annual relative humidity and annual rainfall showed an inverse relation with time, while the reverse is true for the temperature. The same relations were noticed for Wasit and Baghdad stations (Figures 3 and 4). Such results are in accordance with those described by Adamo et al. 2020 [14] and Majeed et al. 2020 [15], concluding that Iraq faces severe climate change impacts.

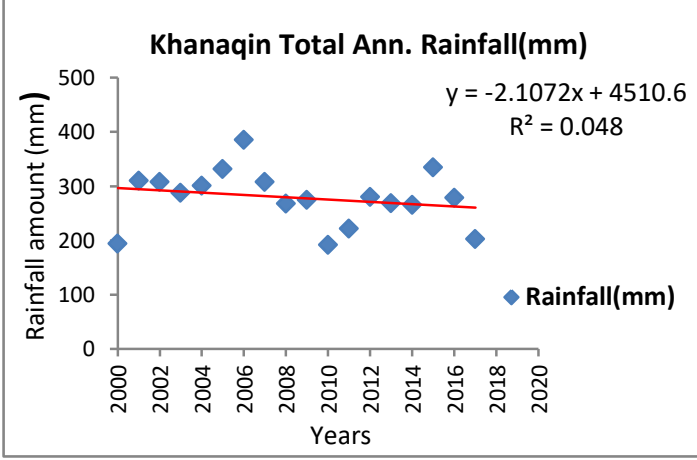

(A)

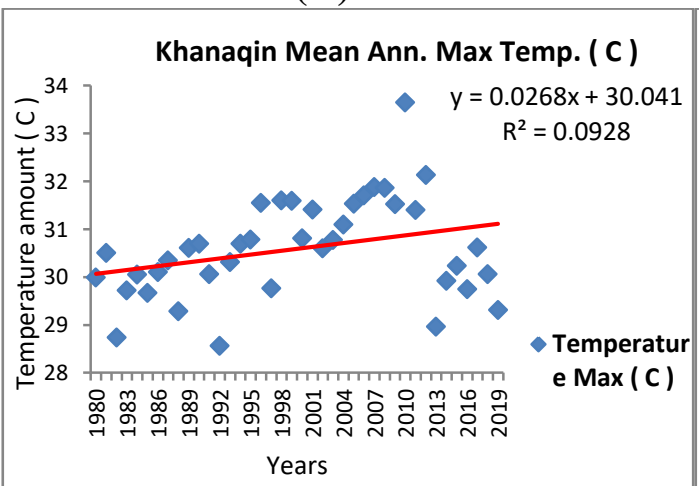

(C)

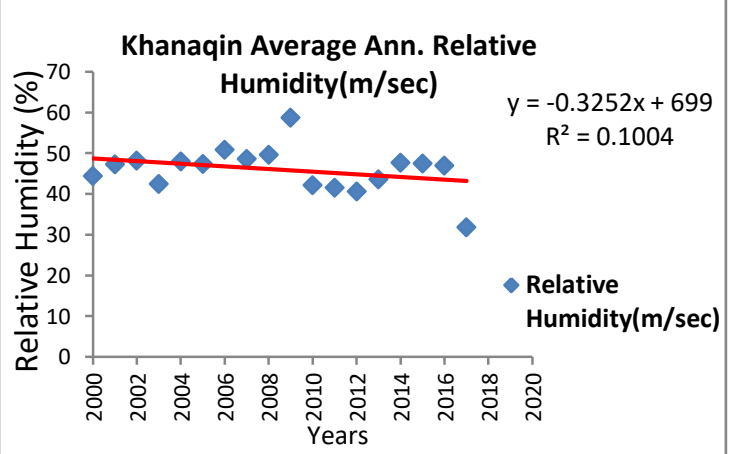

(B)

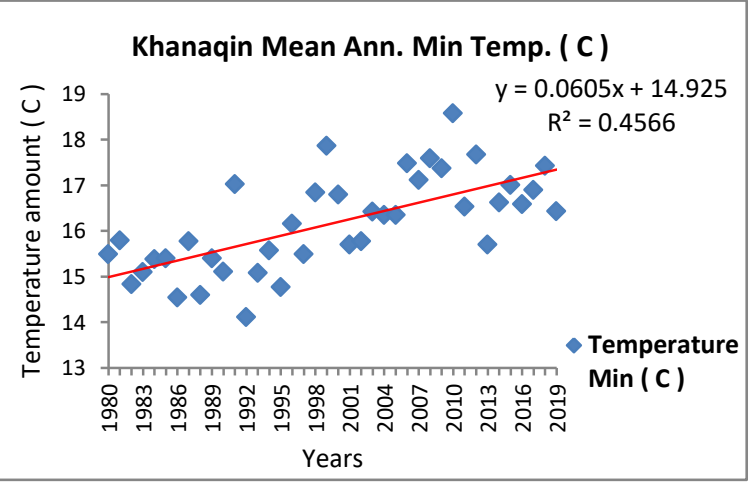

(D)

Figure 2- The trends of annual rainfall (mm) (A), annual relative humidity (\%) (B), annual mean max. temperature $\left(\mathrm{c}^{0}\right)(\mathrm{C})$, and annual mean min. temperature $\left(\mathrm{c}^{\circ}\right)(\mathrm{D})$ at KhanaqinDiyala Governorate during 2000-2019. 

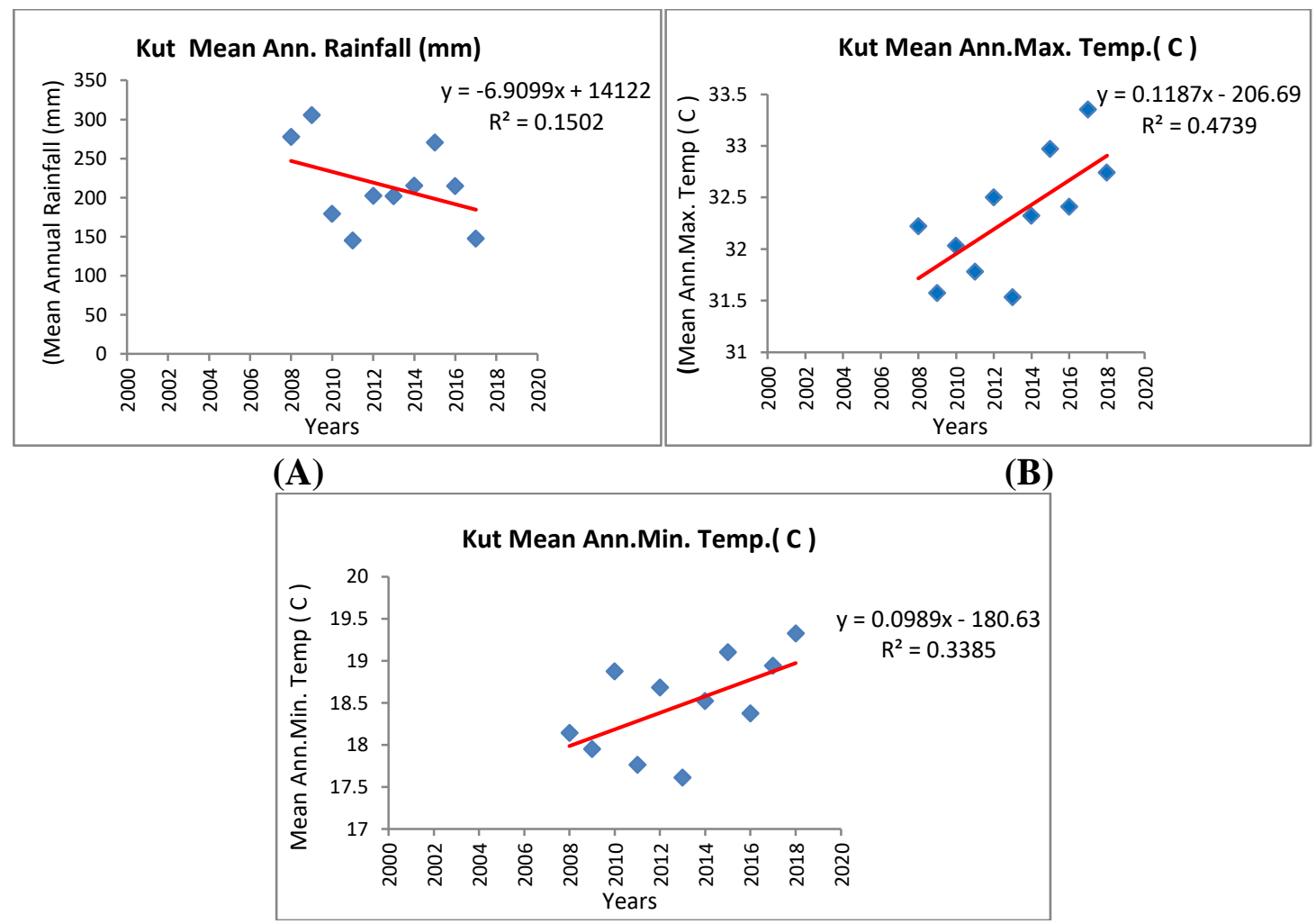

(C)

Figure 3- The trends of annual rainfall $(\mathrm{mm})(\mathrm{A})$, annual mean max. temperature $\left(\mathrm{c}^{\circ}\right)(\mathrm{B})$ and annual mean min. temperature $\left(C^{\circ}\right)(C)$ in Kut station, Wasit governorate, during 2000-2019.

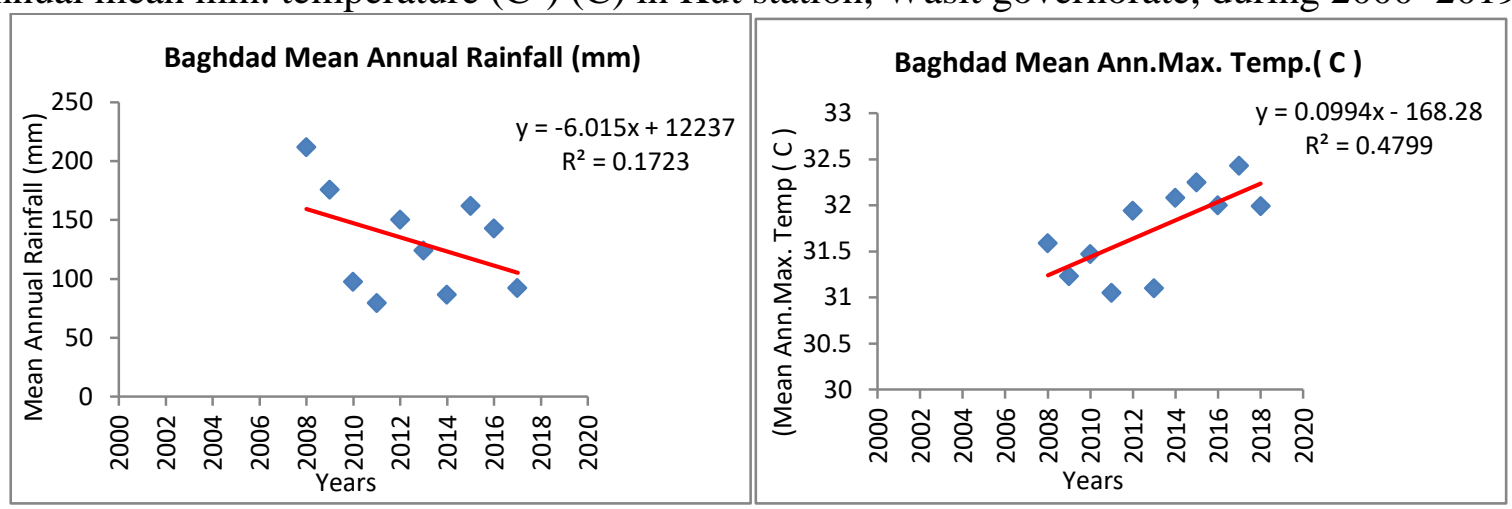

(A)

(B)

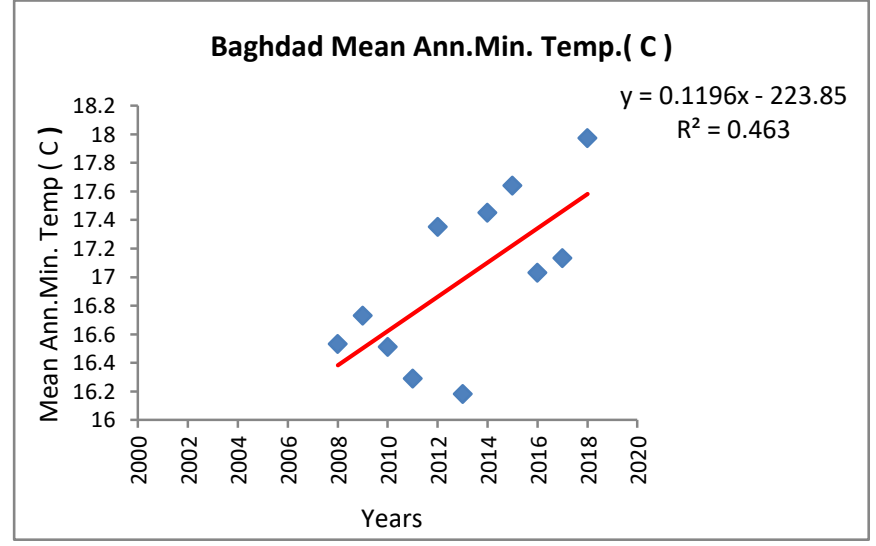

(C)

Figure 4- The trends of annual rainfall $(\mathrm{mm})(\mathrm{A})$, annual mean max. temperature $\left(\mathrm{c}^{\mathrm{o}}\right)(\mathrm{B})$ and annual mean min. temperature $\left(C^{\circ}\right)(C)$ for Baghdad during 2000-2019. 


\section{The analysis of the climatic parameters of Khanaqin area}

We also evaluated the climate parameters in terms of hydrological and hydrogeological impacts, aiming to develop a formula for water balance of Khanaqin basin.

\section{Rainfall (mm)}

The rainfall period in Khanaqin area is characterized by very little rain in summer (JuneAugust) and low amounts in September, with rainy months from October to May. Rainfall has an impact on the groundwater amount and soil moisture. It is also a vital climate parameter that is employed to evaluate climate water balance and groundwater recharge. The monthly average values of rainfall recorded in Khanaqin for the period 1981-2019 are shown in Table 1. The maximum value of rainfall was noticed in January $(43.92 \mathrm{~mm})$, whereas the value reached $0.5 \mathrm{~mm}$ in July. The mean annual rainfall of the study area reached $260.86 \mathrm{~mm}$.

\section{Relative Humidity (\%)}

Relative humidity (\%) is the amount of water vapor absorbed by air, which depends on temperature of air and water. Relative humidity is correlated inversely with the temperature, evaporation, and wind speed and directly with rainfall. The highest monthly average of relative humidity for the period 1981-2019 appeared in January (75.12 \%) while the lowest appeared in July $23.93 \%$ are shown in Table 1.

\section{Mean Temperature $\left(\mathrm{C}^{\circ}\right)$}

Temperature varies periodically in the water year and is good coefficient in climate water balance. Temperature represents an important factor that affects evaporation and evapotranspiration.Temperature is correlated inversely with rainfall and relative humidity and directly with the evaporation. The data of temperature for the period 1981-2019 indicated that the highest monthly average appeared in July $\left(36.13 \mathrm{C}^{\circ}\right)$ while the lowest appeared in January $\left(10.1 \mathrm{C}^{\circ}\right)$ are shown in Table 1.

\section{Mean Monthly Evaporation (mm)}

Evaporation is an important element in water balance and hydrological cycle and it is one of the water loss parameters connected with the other factors of temperature, wind speed, sun shine, and area of evaporation surfaces. Both water quality and quantity are affected by evaporation. High evaporation leads to the deposition of salts in the soil, as in the case of the evaporate minerals. Evaporation is correlated inversely with rainfall and relative humidity and directly with temperature. The results of monthly average of evaporation for the period 19812019 as in (Table 1) showed that the highest value appeared in July $(510.5 \mathrm{~mm})$ while the lowest appeared in January $(66.27 \mathrm{~mm})$. The annual evaporation rate of the study area reached $3119.59 \mathrm{~mm}$.

\section{Sunshine}

This factor has influences on the temperature, relative humidity, and the real evapotranspiration. It is one of the climate elements that have major effects on the amount of the evaporated water, where the sun hours be longer in summer and shorter in winter. The monthly average of sunshine hours for the period 1981-2019 as in (Table 1) highest values in July (11.73h/day) while the lowest appeared in January (5.21 h/day).

\section{Wind Speed}

The wind has a major impact on the amount of evaporation. The rate of evaporation increases with the excess of the wind speed. Wind is firmly connected with temperatures and air pressure, where wind speed increases in high temperatures. The most prevailing wind direction in the studied area is northwest during most of the season. The monthly average of wind speed for the period 1981-2019 as in (Table 1) was maximum in April (2.3 m/sec) while the minimum appeared in December $(1.48 \mathrm{~m} / \mathrm{sec})$.

\section{Potential Evapotranspiration}

The potential evapotranspiration (PE) is an important indicator in water budget. Water evaporation is result from surface water or from plants by transpiration [3]. Actual 
evapotranspiration is the real amount of evaporation and transpiration of the surface under climatic factors. Thus, actual water evaporation is very important among the factors of water balance to an area. It aids to determine the amounts of drainage and storage in shallow basins and subsurface percolation.

Thornthwiate (1948) [8] assumed that there is a strong correlation between the mean temperature and other variables such as wind speed and sunshine. The correlation is shown in the following Wilson (1971) equation [13]:

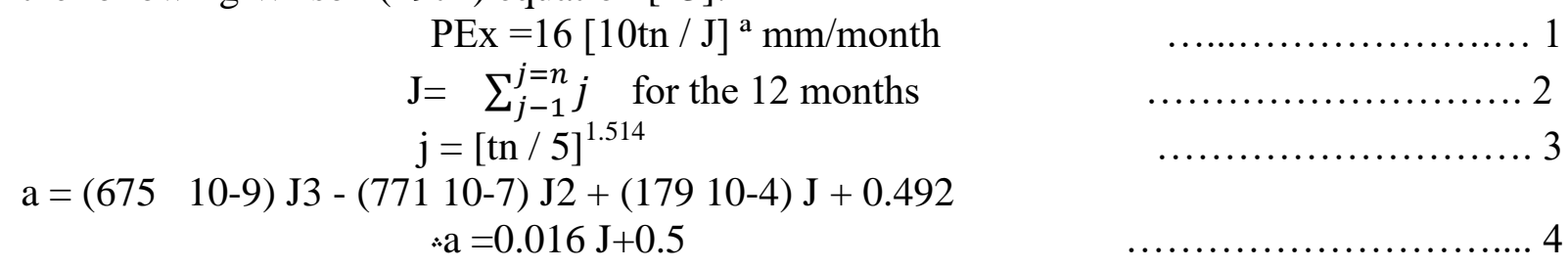

where $\mathrm{a}=2.67664$

$\mathrm{PEx}=$ monthly potential evapotranspiration $(\mathrm{mm} / \mathrm{month})$.

$\mathrm{t}=$ mean air temperature $\left(\mathrm{C}^{\circ}\right)$ for each month .

$\mathrm{n}=$ monthly measurement number.

$\mathrm{J}=$ yearly heat index $\left(\mathrm{C}^{\circ}\right)$

$\mathrm{j}=$ temperature parameter $\left(\mathrm{C}^{\circ}\right)$ for each month.

$\mathrm{a}=$ constant.

The potential evapotranspiration value, however, is a theoretical standard. The values for each month depend on 30 days and $12 \mathrm{hr}$ daily sunshine. The value of the corrected potential evapotranspiration (PEc) may be calculate as [13]:

where:

$\mathrm{PEc}=\mathrm{PEx} \quad * \mathrm{DT} / 360$

PEc: the corrected value of potential evapotranspiration $(\mathrm{mm})$.

PEx: potential evapotranspiration $(\mathrm{mm})$.

D: days number in each month.

T: average number of hours between sunrise and sunset in the month .

The monthly potential evapotranspiration values and the highest value of PEc appeared in July $(215.55 \mathrm{~mm})$ while the lowest appeared in January $(3.61 \mathrm{~mm})$ (Table 2). the values of potential evapotranspiration (PEx) was computed according to equation (1) and corrected them according to equation (4) and These two equations which were applied by Thornthwaite (1948) depending on the monthly temperature. According to the values of evaporation (Epan), the following correlation was recognized:

The yearly period from January to December is characterized by the following order of values: Epan > PEx > PEc.

The evaporation (Epan) was $3119.59 \mathrm{~mm}$ and the rate of evaporation of the corrected potential evapotranspiration (PEc) was $934.84 \mathrm{~mm}$, while the rate of the potential evapotranspiration (PEx) was $1134.23 \mathrm{~mm}$. The observed difference between the three values refers to the differences in the measuring ways (field and calculated values).

Table 2- Corrected potential evapotranspiration values of Khanaqin area calculated for the period 1981-2019 using Thornthwaite (1948) method [8].

\begin{tabular}{|c|c|c|c|c|c|c|}
\hline Month & $\mathbf{t}\left(\mathbf{C}^{\mathbf{0}}\right)$ & $\mathbf{j}=(\mathbf{t n} / \mathbf{5})^{\mathbf{1 . 5 1 4}}$ & $\mathbf{D T} / \mathbf{3 6 0}$ & $\begin{array}{c}\text { PEx } \\
(\mathbf{m m})\end{array}$ & $\begin{array}{c}\text { PEc } \\
(\mathbf{m m})\end{array}$ & $\begin{array}{c}\text { Epan } \\
(\mathbf{m m})\end{array}$ \\
\hline Oct. & 25.77 & 11.97 & 0.28 & 91.77 & 56.98 & 231.49 \\
\hline Nov. & 17.33 & 6.57 & 0.25 & 32.71 & 18.92 & 113.52 \\
\hline Dec. & 12.15 & 3.83 & 0.24 & 12.99 & 7.48 & 75.39 \\
\hline Jan. & 10.10 & 2.90 & 0.11 & 8.04 & 3.61 & 66.27 \\
\hline Feb. & 11.97 & 3.75 & 0.22 & 12.50 & 6.48 & 99.03 \\
\hline Mar. & 15.96 & 5.80 & 0.35 & 26.40 & 18.07 & 174.86 \\
\hline
\end{tabular}




\begin{tabular}{|c|c|c|c|c|c|c|}
\hline Apr. & 21.63 & 9.18 & 0.45 & 58.20 & 44.96 & 244.98 \\
\hline May. & 28.60 & 14.02 & 0.57 & 120.32 & 109.10 & 346.28 \\
\hline Jun. & 33.31 & 17.66 & 0.51 & 178.85 & 149.94 & 456.29 \\
\hline Jul. & 36.13 & 19.97 & 0.64 & 220.93 & 215.55 & 510.50 \\
\hline Aug. & 35.79 & 19.69 & 0.59 & 215.56 & 199.91 & 458.02 \\
\hline Sep. & 31.60 & 16.31 & 0.34 & 155.95 & 103.84 & 342.96 \\
\hline Total & 280.33 & $\mathrm{~J}=131.63$ & DT/360 & 1134.23 & 934.84 & 3119.59 \\
\hline
\end{tabular}

\section{Water deficit (WD) and water surplus (WS)}

According to Lerner et al. [9], the actual potential evapotranspiration (APE) is derived as: $\mathrm{APE}=\mathrm{PEc} \quad$ when $\mathrm{P} \geq \mathrm{PEc}$ $\mathrm{APE}=\mathrm{P} \quad$ when $\mathrm{P}<\mathrm{PEc}$

In the first case (water surplus), values of rainfall are higher than those of the corrected potential evapotranspiration and actual potential evapotranspiration is equal to the corrected potential evapotranspiration. Whereas in the water deficit case, values of rainfall are higher than those of the corrected potential evapotranspiration, while the actual potential evapotranspiration is equal to rainfall values, as expressed in the following relations :

$\mathrm{P}>\mathrm{PEc}, \quad \mathrm{APE}=\mathrm{PEc}$

$$
\mathrm{WS}=\mathrm{P}-\mathrm{PEc}
$$

$\mathrm{P}<\mathrm{PEc}, \quad \mathrm{APE}=\mathrm{P}$

$$
\mathrm{WD}=\mathrm{PEc}-\mathrm{P}
$$

Where:

WS: water surplus (mm).

WD: water deficit (mm)

P: rainfall $(\mathrm{mm})$

APE: potential evapotranspiration $(\mathrm{mm})$ actual.

PEc: potential evapotranspiration $(\mathrm{mm})$ corrected.

The monthly average values of APE, WS, and WD are shown in (Table 3). The water surplus amount is $147.24 \mathrm{~mm}$ from total rainfall $(260.86 \mathrm{~mm})$ and it is limited between November to March because rainfall exceeds PEc; therefore, from the annual rainfall, the water surplus ratio is :

$$
\mathrm{WS} \%=\mathrm{WS} / \mathrm{P} \times 100
$$

$\mathrm{WS} \%=147.24 / 260.86 \times 100=56.44 \%$

This amount indicates the values of the surface runoff and the recharge to the ground water. While the water deficit amount is $821.21 \mathrm{~mm}$ from PEc, which equals $43.56 \%$ from the total rainfall, as in the following equation:

$$
\mathrm{WD} \%=100-\mathrm{WS} \%
$$

$\mathrm{WD} \%=100-56.44 \%=43.56 \%$

Table 3- Measured monthly average values of water deficit and water surplus for Khanaqin Station for the period 1981-2019.

\begin{tabular}{|c|c|c|c|c|c|}
\hline Months & $\begin{array}{c}\text { P } \\
(\mathbf{m m})\end{array}$ & $\begin{array}{c}\text { PEc } \\
(\mathbf{m m})\end{array}$ & $\begin{array}{c}\text { PEx } \\
(\mathbf{m m})\end{array}$ & $\begin{array}{c}\text { WS } \\
(\mathbf{m m})\end{array}$ & $\begin{array}{c}\text { WD } \\
(\mathbf{m m})\end{array}$ \\
\hline Oct. & 14.73 & 25.7 & 14.73 & 0.00 & 42.25 \\
\hline Nov. & 42.92 & 8.18 & 8.18 & 24.00 & 0.00 \\
\hline Dec. & 41.66 & 3.12 & 3.12 & 34.18 & 0.00 \\
\hline Jan. & 43.92 & 0.88 & 0.88 & 40.31 & 0.00 \\
\hline Feb. & 35.31 & 2.75 & 2.75 & 28.83 & 0.00 \\
\hline Mar. & 37.99 & 9.24 & 9.24 & 19.92 & 0.00 \\
\hline Apr. & 29.40 & 26.19 & 26.19 & 0.00 & 15.56 \\
\hline May. & 11.25 & 68.58 & 11.25 & 0.00 & 97.85 \\
\hline Jun. & 0.84 & 91.21 & 0.84 & 0.00 & 149.1 \\
\hline
\end{tabular}




\begin{tabular}{|c|c|c|c|c|c|}
\hline Jul. & 0.50 & 141.39 & 0.50 & 0.00 & 215.05 \\
\hline Aug. & 0.64 & 127.18 & 0.64 & 0.00 & 199.27 \\
\hline Sep. & 1.71 & 53.02 & 1.71 & 0.00 & 102.13 \\
\hline Total & 260.86 & 557.46 & 80.03 & 147.24 & 821.21 \\
\hline
\end{tabular}

\section{Khanaqin Climate Classification}

There are several climate classification models that can be applied to determine the type of the climate. Three of these classifications were used to find the type of Khanaqin climate, as follows :

\section{A- Mather (1974) [12] classification:}

Climate was classified into three classes, according to the climate index of Mather [12], based on the relationship between rainfall and evapotranspiration. The climate index is given as:

$$
\operatorname{Im}=[(\mathrm{P} / \mathrm{PE})-1] * 100
$$

where:

$\operatorname{Im}=$ Aridity index

$\mathrm{P}=$ Rainfall

$\mathrm{PE}=$ Potential evapotranspiration.

When Im has a negative value, then it represents dry climate, whereas a positive value represents a humid climate. According to this classification, our results for the studied area showed that Aridity index $(\mathrm{Im})=-91.63$, while the climate type is arid, as shown in (Table 4).

Table 4- Classification of the climate in the study area according to Mather, 1974[13].

\begin{tabular}{|c|c|c|}
\hline Climate Type & Range of $\mathbf{I m}$ & \multirow{2}{*}{$\begin{array}{c}\mathbf{I m}=-91.63 \\
\text { in the studied area }\end{array}$} \\
\hline Dry-sub humid & 0.0 to -33.3 & \\
\hline Semi-Arid & -33.3 to -66.7 & \\
\hline Arid & -66.7 to -100 & \\
\hline
\end{tabular}

\section{B- Brown and Cocheme, 1973 [11] classification}

According to Brown and Cocheme [11] classification, the humidity index (H.I) depends on the ratio between rainfall and potential evapotranspiration, as shown in the following equation (Table 5).

H.I: Humidity index.

$$
\text { H.I }=\mathrm{P} / \mathrm{PE}
$$

P: Annual rainfall (mm).

PE: Potential evapotranspiration ( $\mathrm{mm})$.

From equation 11, the results of the studied area showed a value of H.I $=0.47$, reflecting climate between moist and dry .

Table 5- Classification of the climate according to Brown and Cocheme, 1973 [11].

\begin{tabular}{|c|c|c|}
\hline $\mathrm{HI}>1$ & Wet & 1 \\
\hline $0.5<\mathrm{HI}<1$ & Moist & 2 \\
\hline $0.25<\mathrm{HI}<0.5$ & Between moist and dry & 3 \\
\hline $0.1<\mathrm{HI}<0.25$ & Dry & 4 \\
\hline $\mathrm{HI}<0.1$ & Very dry & 5 \\
\hline
\end{tabular}

\section{C- Koeppen, 2006 [10] classification}

Koeppen classification is one of the most commonly used systems for classifying the world climate, as shown in (Figure 5) [10]. It recognizes five major climate types based on the annual and monthly averages of temperature and precipitation, where the temperature is measured in $\mathrm{C}^{\circ}$ and precipitation in $\mathrm{cm} / \mathrm{month}$. The application of this classification system in 
the present study revealed that the climate of the studied area belongs to the BSh class (steppe with hot arid).

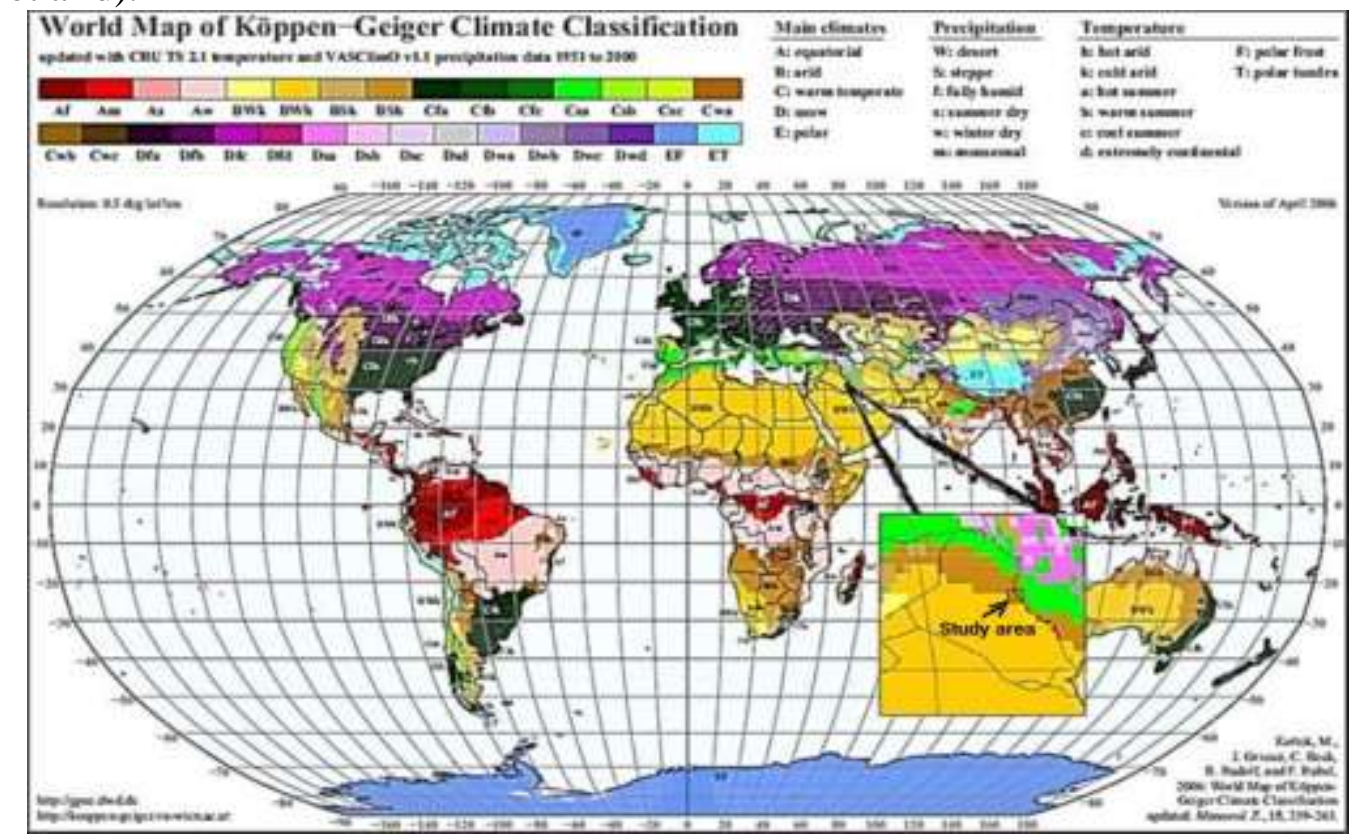

Figure 5- Koeppen world climate classification [10].

\section{Conclusions}

The frequency curves of annual rainfall, annual relative humidity, and annual mean temperature (average, maximum and minimum) for the years 2000-2019 were studied.

Negative relationships between rainfall and annual relative humidity with time were indicated for Baghdad, Diyala, and Kut stations, with a remarkable decrease in rainfall amounts and $\mathrm{RH} \%$. While, positive relationship between annual mean temperature (maximum and minimum) and time reflected a remarkable increase in temperature values.

For Khanaqin Station, the annual averages of the climatic parameters for the years 1981 2019 reflected a noticeable decrease in rainfall values and annual relative humidity, indicating the global change of climate. The total annual rainfall was $260.86 \mathrm{~mm}$ and evaporation was $3119.59 \mathrm{~mm}$, while the mean monthly relative humidity was $46.65 \%$, sunshine was 8.39 $\mathrm{h} /$ day, temperature was $23.36 \mathrm{C}^{0}$, and wind speed was $1.86 \mathrm{~m} / \mathrm{sec}$. The climate water balance was also calculated. When analyzing the results, it was found that there was a large water deficit due to high temperature and thus increased evaporation rate.

Also, a total water surplus was found in Khanaqin area $(147.24 \mathrm{~mm})$ in the months of November to March. The climate classification of Khanaqin area showed semi dry to dry climates. Also, the region has a great water deficit of up to $43.56 \%$ of the total rainfall values.

\section{REFERENCES}

[1] Buchdahl J. Climate Change, review, of global contemporary and prehistoric. :99, Http://cdiac.org.gov, 1999.

[2] Judith L. \& David. "The Sun and climate". Consequences, vol. 2, no. 1, Winter 1996.

[3] Schimel, D., Enting, I.G., Heimann, M, Wigley, T.M.L., Raynaud, D., Alves, D. \& Siegenthaler, U., "CO2 and the carbon cycle". In: Climate Change 1995: Radiative Forcing of Climate Change, and an Evaluation of the IPCC IS92 Emission Scenarios, Intergovernmental Panel on Climate Change (IPCC), Houghton, J.T., Meira Filho, L.G., Bruce, J., Lee, H., Callander, B.A., Haites, E., Harris, N. \& Maskell, K.(eds.). Cambridge University Press, Cambridge, pp. 35-71, 1995.

[4] https://power.larc.nasa.gov/data-access-viewer/ NASA, Climatic data.

[5] Bronstert A., "Rainfall-runoff modelling for assessing impacts of climate and land-use change". Hydrological Processes. 2004; vol. 18, no. 3, pp. 567-570, 2004. 
[6] Oleiwi A., "Hydrogeological and Environmental study of Khanaqin area, Northeast of Iraq", Master of Science in Geology, 2014.

[7] Al-Sudani H. I., "Hydrochemical Evaluation and Utilization of Groundwater in Khanaqin Area, Diyala Governorate - East of Iraq", Iraqi Journal of Science, 2018, vol. 59, no.4C, pp. 22792288, 2018.

[8] Thornthwait, C.W., "An Approach toward a Relation Classification of Climate", Geographical Review, vol. 32, pp. 55, 1948.

[9] Lerner, N. D., Issar, A. S., Simmers, I., Groundwater recharge- a Guide to understanding and estimating natural recharge, Vol.8, Association of Hydrogeologist, Hanover, ISBN 3-922705-91X, 1990.

[10] Kottek, M. J., Grieser, C., Beck, B. Rudolf, and Rubel, F., 2006. "World Map of Köppen- Geiger Climate Classification updated", Meteorol, Z., vol. 15, pp. 259-263, 2006.

[11] Brown, L.H., and Cocheme, J., A study at the agromeleorblogy of the High Land of eastern Africa, WMO, Geneva, Tech. Note, No. 125, pp. 197, 1973.

[12] Mather, J. R. Climatology Fundamentals and Applications, McGraw-Hill Book Co., New York, 1974, p. 412.

[13] Wilson, E.M., Engineering hydrology, McGraw-Hill Press. Ltd., 1971 P. 182.

[14] Adamo, N, Al-Ansari, N, and Sissakian K. N, "Global Climate Change Impacts on Tigris Euphrates Rivers Basins". Journal of Earth Sciences and Geotechnical Engineering, vol.10, no.1, pp. 49-98, 2020.

[15] Majeed H. M. S., Raja K. Ahmed, Suhad, S. Khalaf, Ruqaya Ahmed M. Amin, Tanzeeh ,M. Hameed, "Spectral indices analysis in detection of the thermal variability for Baquba city and its environmental effects with the support of GIS \& R.S technique", Journal of University of Shanghai for Science and Technology ISSN: 1007-6735, vol. 22, Issue 11, pp.702 -711, 2020. 